\title{
PENERAPAN PARK AND RIDE DI STASIUN BEKASI
}

\author{
The Implementation of Park and Ride at Bekasi Station
}

Mega Suryandari ${ }^{1}$, Achmad Wicaksono $^{1}$ dan Imma Widyawati Agustin²

\begin{abstract}
Abstrak: Tujuan penelitian ini untuk mengetahui penerapan park and ride di Stasiun Bekasi. Metode yang digunakan penelitian ini adalah dengan penilaian kinerja parkir berdasarkan standar dan persepsi pengguna parkir dengan model kano, dan Analytic Hierarchy Process (AHP) untuk menganalisis penerapan park and ride di Stasiun Bekasi. Hasil penelitian menunjukan kinerja parkir tidak memenuhi standar. Kinerja parkir Stasiun Bekasi bermasalah dilihat dari dua perspektif yaitu: akumulasi puncak melebihi kapasitas parkir dan indeks parkir lebih dari 1 (satu). Perbaikan kinerja parkir berdasarkan persepsi pengguna parkir dengan Model Kano, prioritas utama adalah garis parkir yang jelas dan sesuai standar. Prioritas penerapan park and ride di Stasiun Bekasi adalah penyediaan lahan parkir 28,48\%. Dari hasil penelitian ini penulis merekomendasikan pembangunan gedung parkir sesuai persepsi pengguna parkir dan penerapan park and ride sebagai solusi jangka panjang.
\end{abstract}

Katakunci: Park-and-ride, Parking, Kano-Model, Analytic-Hierarchy-Process

\begin{abstract}
The purpose of this research is to know the implementation of park and ride at Bekasi Station. The method of analysis in this research is the assessment of parking performance based on standards and parking user perception with Kano-model, and the Analytic-Hierarchy-Process (AHP) to analyze the implementation of park and ride at Bekasi Station. The results show that parking performance doesn't meet the standard. The problem of parking performance at Bekasi Station are view from two perspectives, namely: the peak accumulation which is more than its capacity and parking index which is more than 1 (one). Improved performance based on user perception parking with Kano Model, the main priority is obvious parking lines and the parking standard. The priority of implemention of park and ride at Bekasi Station is provideparking $28.48 \%$. From the results of this research, the writter recommends to build a parking in conformity with the parking user's perception for short term solution and the implementation of park and ride for the long term solution.
\end{abstract}

Keyword: Park-and-ride, Parking, Kano-Model, Analytic-Hierarchy-Process

\footnotetext{
${ }^{1}$ Jurusan Teknik Sipil, Universitas Brawijaya, Indonesia

${ }^{2}$ Jurusan Perencanaan Wilayah dan Kota, Universitas Brawijaya, Indonesia
} 


\section{Pendahuluan}

Peningkatan permintaan angkutan kereta api harus bersamaan dengan kualitas pelayanan seperti penyediaan fasilitas pelayanan yang optimal terutama di Stasiun Bekasi. Berdasarkan Rencana PT. KAI DAOP 1 menargetkan1,2 juta penumpang perhari di tahun 2018, target tersebut berdampak khususnya dalam persentase tinggi dalam jumlah penumpang dari dan menuju ke Jakarta dan Stasiun Bekasi (Virginia, 2013).

Dalam kajian analisis park and ride di Kota Bekasi, pada beberapa stasiun kerata api telah berkembang tempat penitipan kendaraan pribadi, dimana pengguna kendaraan pribadi menggunakan kendaraannya dari rumah lalu parkir kendaraannya pada tempat penitipan kemudian melanjutkan perjalanan dengan angkutan umum. Pola ini sering disebut dengan sistem Park and ride, dimana di beberapa negara sering dijadikan sebagai suatu strategi untuk mengurangi penggunaan kendraaan pribadi menuju pusat kota(Dishub Kota Bekasi, 2012). Cara yang efektif pengguna transportasi publik ke area kepadatan rendah dimana para komuter masih dapat menggunakan kendaraan pribadiuntuk mengawali perjalanan sehingga berganti menggunakan angkutan umum dengan penerapan park and ride(Farhan, 2003).

Dari survei dilapangan, tempat penitipan resmi yang dikelola PT KAI ada 2 lokasi parkir dengan sistem e-parkingreska dimana tarif parkir mangalami kenaikan dan belum adanya perbaikan dari segi keamanan dan kenyamanan pengguna parkir.Meningkatnya jumlah penumpang KRL yang turut mempengaruhi ketersediaan lahan parkir di area stasiun yang terbatas dengan kondisi parkir yang tidak memperhatikan standar yang berlaku untuk fasilitas parkir sehingga perlu adanya penataan parkir yang sesuai standar. Solusi untuk bertambahnya pengguna parkir diperlukan adanya fasilitas perpindahanpengguna kendaraan pribadi ke KRL(Kereta Rel Listrik). Upaya tersebut dikembangkan dengan fasilitas perpindahan moda dengan memperbanyak fasilitas alih moda dengan pengembangan sistem park and ride di Stasiun Bekasi.

\section{Metode Penelitian}

Lokasi penelitian yang berada di Kota Bekasi, Jawa barat, tepatnya di Stasiun Bekasi memiliki 2 lokasi parkir resmi yaitu lahan parkir sisi selatan dan lahan parkir sisi utara. Lahan parkir resmi di Stasiun Bekasi terdiri dari parkir motor dan mobil yang sudah menggunakan sistem e-parking reska (Gambar 1).

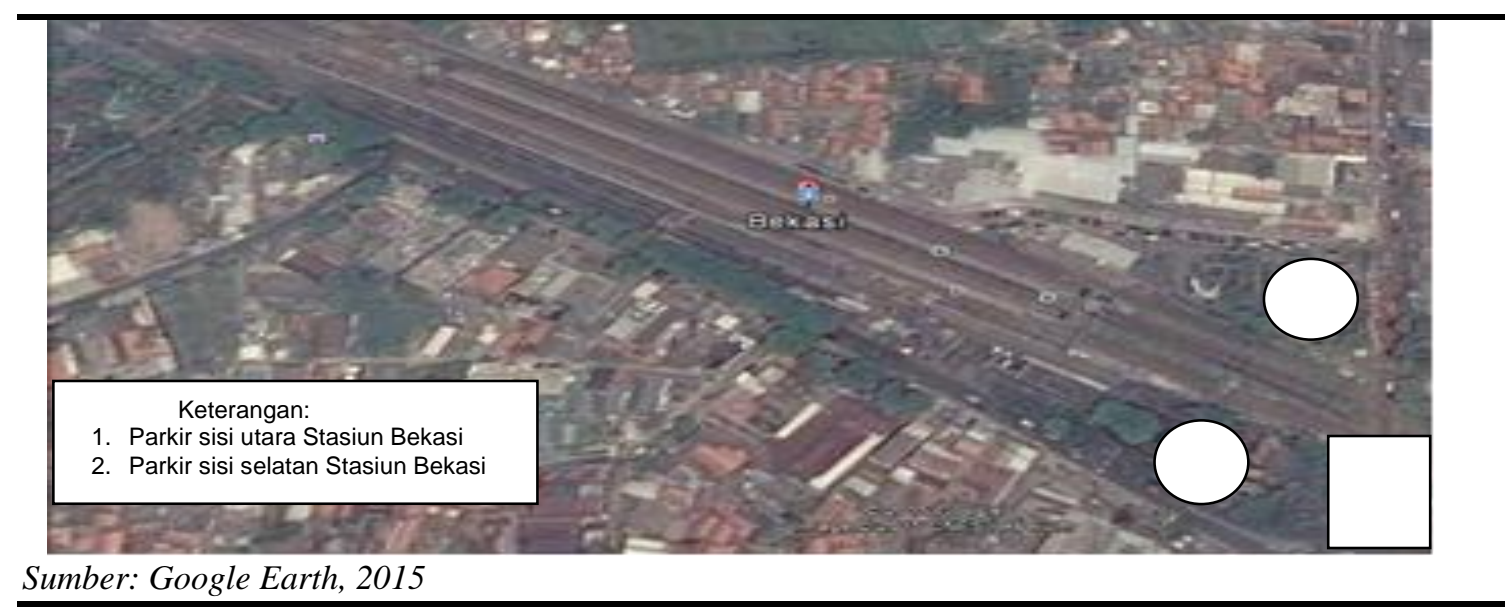

Gambar 1. Lokasi Penelitian 
Dalam penelitian ini survei kinerja parkir berdasarkan persepsi pengguna parkir dengan jumlah sampel pengguna parkir menggunakan rumus Slovin, populasi pengguna parkir ditentukan dari data survei pada hari jumat, 6 maret 2015 yaitu 1588 kendaraan yang terdiri dari motor 1504 dan mobil 84. Dikarenakan populasi heterogen dan jumlahnya tidak proporsional maka digunakan teknik disproportionatestratified random sampling.Jumlah sampeldigenapkan menjadi 400 responden, sampel pengguna parkir mobil sebanyak 84 dan sampel pengguna motor sebanyak 316. Dibawah ini merupakan hasil perhitungannya:

$$
\begin{aligned}
& \mathrm{n}=\frac{\mathrm{N}}{1+\mathrm{Ne}^{2}} \\
& \mathrm{n}=\frac{1588}{1+\left(1588 \times(0,05)^{2}\right)} \\
& \mathrm{n}=319 \approx 400
\end{aligned}
$$

Pada penelitian ini, langkah pertama adalah survei dan wawancara pendahuluan untuk mengetahui kondisi kinerja parkir di Stasiun Bekasi lalu merumuskan masalah dan tujuan penelitian. Langkah selanjutnya adalah pengumpulan data primer yang berupa survei kinerja parkir berdasarkan standar versus persepsi pengguna parkir dan penerapan park and ride di Stasiun Bekasi berdasarkan persepsi stakeholder. Lalu menganalisis kinerja parkir berdasarkan standar versus persepsi pengguna parkir dengan model kano dan analisis AHP untuk persepsi stakeholder.Rekomendasi penelitian ini adalah perbaikan kinerja parkir dengan penerapan park and ride di Stasiun Bekasi

\section{Analisis Kinerja Parkir berdasarkan Standar}

Penilaian kinerja parkir di Stasiun Bekasi berdasarkan standar Keputusan Dirjen PerhubunganDarat tentang pedoman teknis penyelenggaraan fasilitas parkir dimana item penilaiannya adalah ruang bebas kendaraan parkir, lebar bukaan pintu kendaraan, penentuan satuan ruang parkir (SRP), pola parkir, jalur sirkulasi, dan fasilitas penunjang parkir. Permasalahan parkir diketahui dari karakteristik parkir yaitu kapasitas parkir, akumulasi parkir, indeks parkir (Hobbs, 1979).

\section{Analisis Model Kano}

Untuk mengetahui Persepsi pengguna parkir terhadap fasilitas parkir yang ada di Stasiun Bekasi dengan menggunakan Model Kano. Mengidentifikasi persepsi pengguna parkir di Stasiun Bekasi berdasarkan variabel kenyamanan, keamanan, dan kemudahan parkir (Halim dkk, 2011 dan Chronika dkk, 2008), kinerja petugas parkir (Nurfajriat, 2007), tarif parkir, dan fasilitas tambahan (Ginn, 2009 dan BSTP, 2008) ke dalam diurutkan dalam 4 kategori model kano (Gambar 2) ialah:

1. Must be (atribut dasar): pada kategori ini, ketidakpuasan pengguna akan terjadi apabila suatu atribut tidak ada, tetapi kepuasan pengguna tidak berpengaruh signifikan apabila adanya atribut.

2. One dimensional (atribut yang diharapkan): pada kategori ini, kepuasan pengguna menunjukan hubungan sejajar kinerja suatu atribut.

3. Attractive (atribut kesenangan): pada kategori ini, atribut menunjukan hubungan sejajar antara kepuasan dan kinerja atribut.

4. Indiferent: keberadaan atribut tidak berpengaruh dalam kepusan pengguna 


\section{Analisis Analytic-Hierarchy-Process (AHP)}

Analytic-Hierarchy-Process ialah analisis yang menampung penilaian para ahli dalam rancangan terhadap suatu masalah (Saaty, 1990). Tabel 1 menunjukan bahwa ada 12 responden dalam penentuan prioritas penerapan park and ride di Stasiun Bekasi diketahui dari analisis Analytic Hierarchi Process (AHP) yang expert dalam parkir Stasiun Bekasi diantaranya pihak akademisi, pihak pengguna parkir, operator parkir dan regulator parkir.

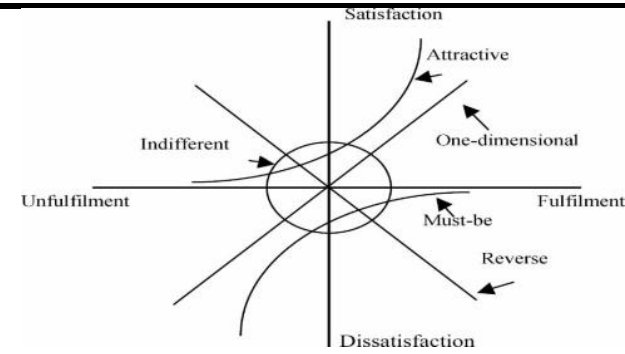

Sumber: Yang, 2005

Gambar 2. Model Kano

Tabel 1. Responden AHP

\begin{tabular}{lr}
\hline \multicolumn{1}{c}{ Instansi } & Jumlah \\
\hline Akademisi(STTD) & 3 0rang \\
Pengguna Parkir(Staf Kemenhub) & 3 Orang \\
Operator (PT.KAI) & 3 Orang \\
Regulator (Dishub Kota Bekasi) & 3 0rang \\
\hline
\end{tabular}

\section{Hasil Dan Pembahasan}

\section{Kinerja Parkir Berdasarkan Standar}

Berdasarkan tabel 2 dapat diketahui bahwa parkir Stasiun Bekasi tidak sesuai dengan standar Keputusan Direktur Jendral Perhubungan Darat nomor: 272/hk.105/DRJD/96 tentang pedoman teknis penyelanggaraan fasilitas parkir. Ketidaksesuaian standar parkir di Stasiun Bekasi salah satunya adalah ukuran garis parkir.

Tabel 2.Kinerja Parkir berdasarkan Standar

\begin{tabular}{|c|c|}
\hline Permasalahan & Penjelasan \\
\hline $\begin{array}{l}\text { Tidak terdapat pintu depan terbuka penuh } \\
\text { dan ditambah untuk pergerakan kursi roda }\end{array}$ & $\begin{array}{l}\text { Tidak tersedia parkir khusus kendaaan } \\
\text { difabel }\end{array}$ \\
\hline $\begin{array}{l}\text { Tidak terdapat ukuran pasti pintu } \\
\text { depan/belakang terbuka penuh }\end{array}$ & $\begin{array}{l}\text { Tergantung kondisi parkir karena kendaraan } \\
\text { yang diparkir tidak di rem tanggan sehingga } \\
\text { ada pengaturanoleh petugas }\end{array}$ \\
\hline Garis parkir mobil & $2,00 \times 4,00 \mathrm{~m} 2$ \\
\hline $\begin{array}{l}\text { Garis parkir motor } \\
\text { Tidak sesuai lebar minimum jalur sirkulasi } \\
\text { jalan satu arah }\end{array}$ & $\begin{array}{l}\text { kondisi parkir motor x } 1,5 \mathrm{~m}^{2} \\
\text { Lebar jalan hanya } 2,5 \mathrm{~m}\end{array}$ \\
\hline Lampu penerangan & $\begin{array}{l}\text { Lampu penerangan yang ada tidak } \\
\text { membantu penerangan kendaraan yang } \\
\text { diparkir }\end{array}$ \\
\hline Tidak ada pos petugas di lahan parkir & Tidak ada pos petugas keamanan parkiran \\
\hline
\end{tabular}




\section{Kapasitas Parkir}

Survei parkir yang dilakukan di Stasiun Bekasi pada Jumat, 6 maret 2015 untuk waktu sibuk pada hari kerja dan Sabtu, 7 maret 2015 untuk waktu sibuk pada hari libur untuk mewakili data kapasitas parkir (Gambar 3) dan akumulasi parkir.Kapasitas parkir sisi selatan adalah motor 418 SRP dan mobil 9 SRP (parkir mobil untuk malam hari) dapat dilihat pada tabel 3 .

Tabel 3. Hasil Perhitungan Kapasitas Parkir Sisi Selatan Stasiun Bekasi

\begin{tabular}{|c|c|c|c|c|}
\hline Keterangan & Sudut parkir & Pola Parkir & Total & $\begin{array}{l}\text { Total } \\
\text { kapasitas }\end{array}$ \\
\hline Motor 1 & 900 & $\begin{array}{l}\text { Satu sisi, pulau ,dua } \\
\text { sisi }\end{array}$ & $\pm 416 \mathrm{~m} 2$ & $\begin{array}{l}192 \\
\text { SRP }\end{array}$ \\
\hline Motor 2 & 900 & $\begin{array}{l}\text { Satu sisi, pulau, satu } \\
\text { sisi }\end{array}$ & $\pm 110 \mathrm{~m} 2$ & $58 \mathrm{SRP}$ \\
\hline Motor 3 & 900 & $\begin{array}{l}\text { Satu sisi, pulau, dua } \\
\text { sisi }\end{array}$ & $\pm 160 \mathrm{~m} 2$ & 80 SRP \\
\hline Mobil 1 & 900 & Satu sisi & $\pm 176 \mathrm{~m} 2$ & 9 SRP \\
\hline Motor 4 & 900 & $\begin{array}{l}\text { Satu sisi, pulau, dua } \\
\text { sisi }\end{array}$ & & 88 SRP \\
\hline \multicolumn{2}{|c|}{ Total SRP motor } & & \multicolumn{2}{|l|}{418 SRP } \\
\hline \multicolumn{2}{|c|}{ Total SRP mobil } & & \multicolumn{2}{|l|}{9 SRP } \\
\hline
\end{tabular}

Kapasitas parkir sisi utara Stasiun Bekasi adalah motor 288 SRP dan mobil 55 SRP(tabel 4). Perhitungan kapasitas parkir di Stasiun Bekasi berdasarkan standar pedoman teknik penyelenggaraan fasilitas parkir.

Tabel 4. Hasil Perhitungan Kapasitas Parkir Sisi Utara Stasiun Bekasi

\begin{tabular}{lllll}
\hline Keterangan & Sudut parkir & Pola Parkir & Total & $\begin{array}{l}\text { Total } \\
\text { kapasitas }\end{array}$ \\
\hline Motor 1 & 900 & Satu sisi, pulau ,dua sisi & $\pm 804 \mathrm{~m} 2$ & 240 SRP \\
Motor 2 & 900 & Satu sisi, pulau, satu sisi & $\pm 96 \mathrm{~m} 2$ & 48 SRP \\
Mobil 1 & 900 & Dua sisi & $\pm 194 \mathrm{~m} 2$ & 16 SRP \\
Mobil 2 & 900 & Dua sisi & $\pm 128 \mathrm{~m} 2$ & 12 SRP \\
Mobil 3 & 900 & Satu sisi & $\pm 65 \mathrm{~m} 2$ & 5 SRP \\
Mobil 4 & 900 & Satu sisi & $\pm 260 \mathrm{~m} 2$ & 22 SRP \\
Total SRP motor & 288 SRP & & \\
\multicolumn{7}{l}{ Total SRP mobil } & 55 SRP & & \\
\hline
\end{tabular}

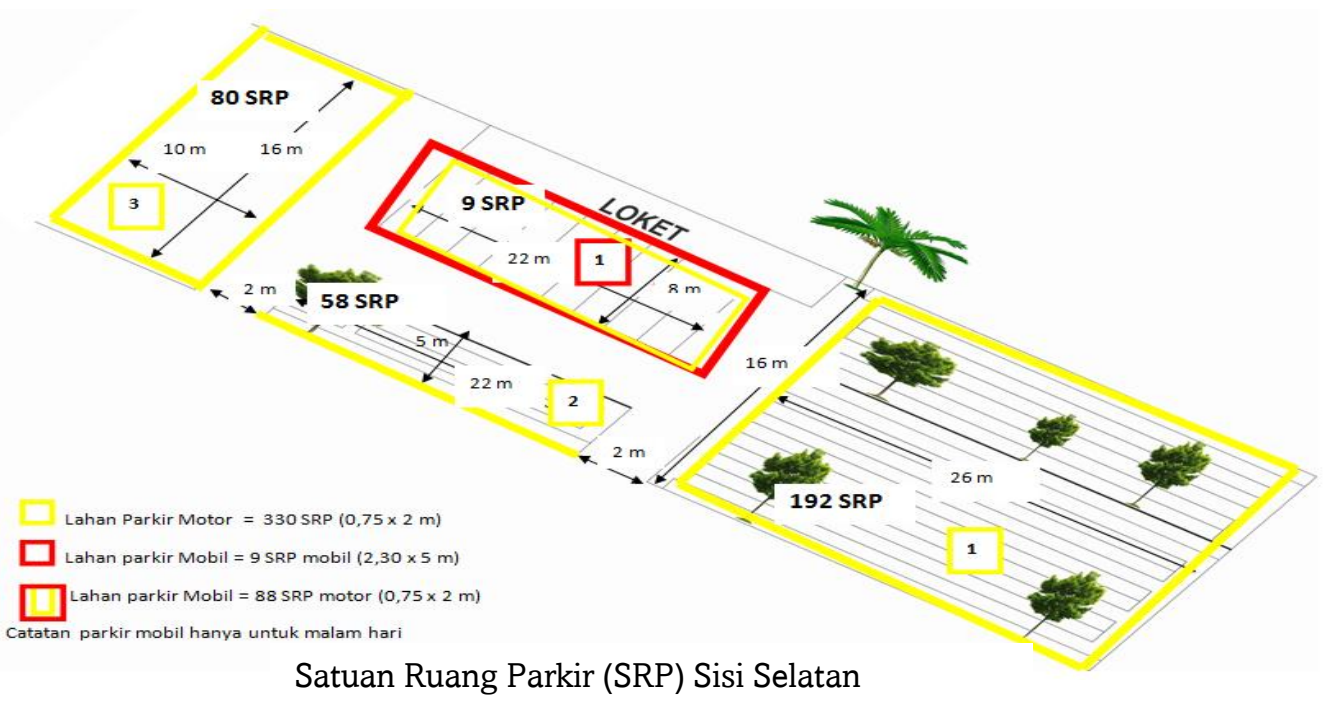




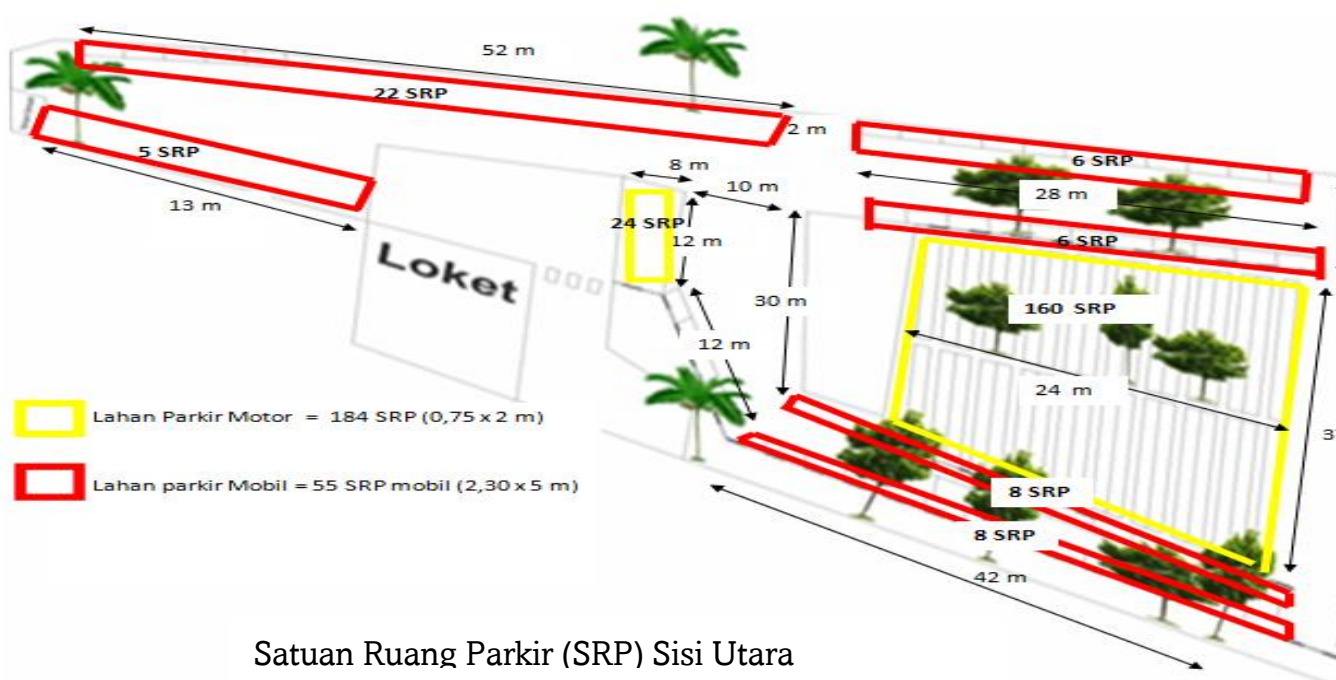

Sumber: Hasil Analisis, 2015

\section{Gambar 3. Satuan Ruang Parkir (SRP) di Stasiun Bekasi}

\section{Akumulasi Parkir}

Gambar 4menunjukan bahwa akumulasi puncak terdapat 756 kendaraan motor lebih dari kapasitas parkir sebesar 338 kendaraan motor, dimana kapasitas yang tersedia adalah 418 kendaraan motor.

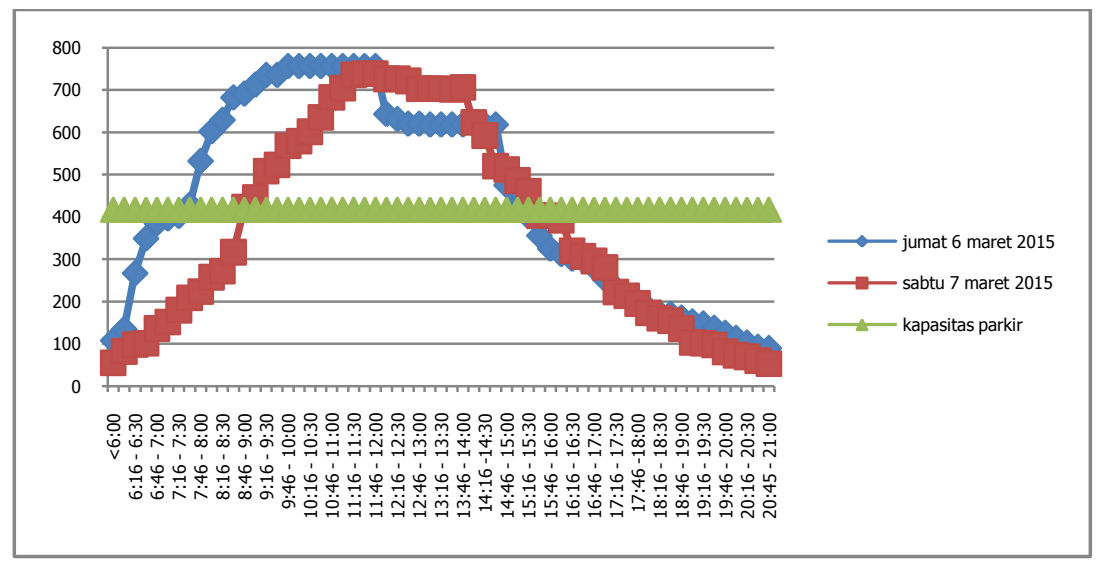

Sumber: Hasil Analisis, 2015

\section{Gambar 4. Grafik Akumulasi Motor terhadap Kapasitas Parkir Sisi Selatan}

Akumulasi puncak terdapat 3 kendaraan angkutan umum (elf) lebih dari kapasitas parkir karena tidak terdapat parkir kendaraan angkutan umum di Stasiun Bekasidapat dilihat pada gambar 5 . 


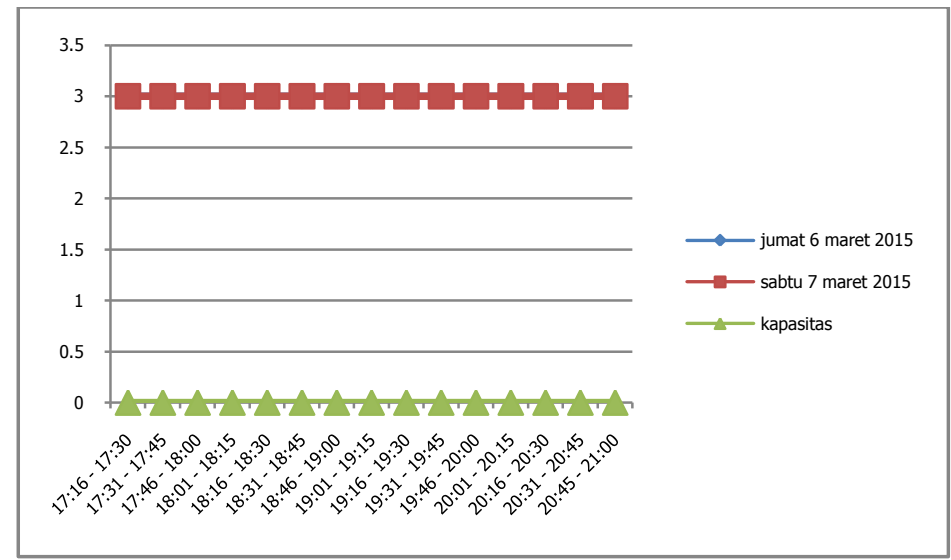

Sumber: Hasil Analisis, 2015

Gambar 5. Grafik Akumulasi Angkutan Umum (elf) terhadap Kapasitas Parkir Sisi Selatan

Akumulasi puncak terdapat 84 kendaraan mobil lebih dari kapasitas parkir sebesar 29 kendaraan, dimana kapasitas yang tersedia adalah 55 kendaraan mobil(gambar 6).Berdasarkan gambar 7 dapat diketahui bahwaAkumulasi puncak terdapat 732 kendaraan motor lebih dari kapasitas parkir sebanyak 444 kendaraan motor, dimana kapasitas yang tersedia adalah 288 kendaraan motor.

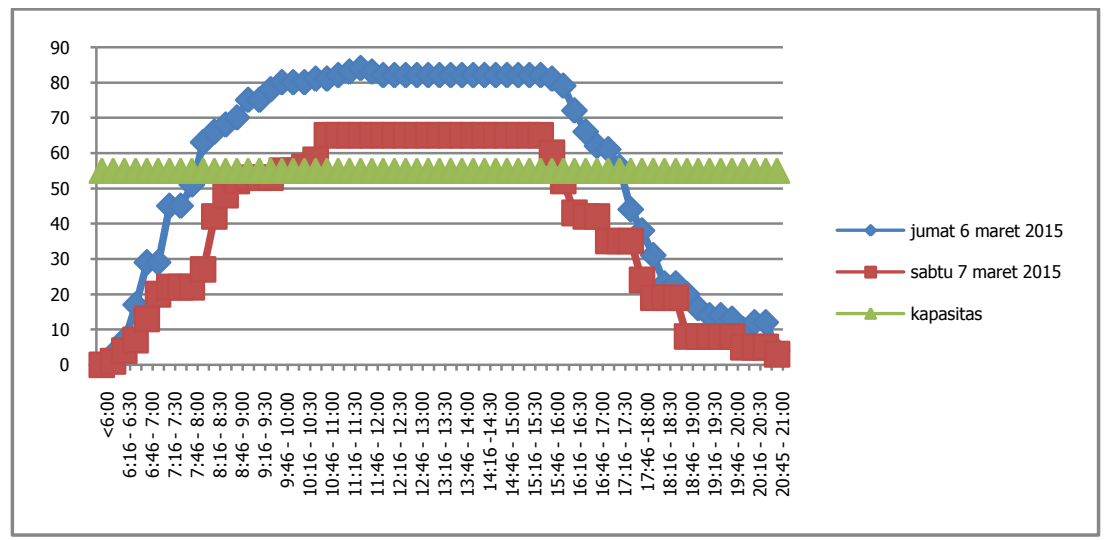

Sumber: Hasil Analisis, 2015

\section{Gambar 6. Grafik Akumulasi Mobil terhadap Kapasitas Parkir Sisi Utara}

Indeks parkir motor tertinggi sebesar 1,81 lebih dari standar indeks parkir sebesar 0,81, dimana standar indeks parkir adalah 1 (gambar 8). Gambar 9 menunjukan bahwa Indeks parkir motor tertinggi adalah 2,54 lebih dari standar indeks parkir sebesar 1,54. Indeks parkir tertinggi adalah 1,53 lebih dari standar indeks parkir sebesar 0,53 (gambar $10)$. 


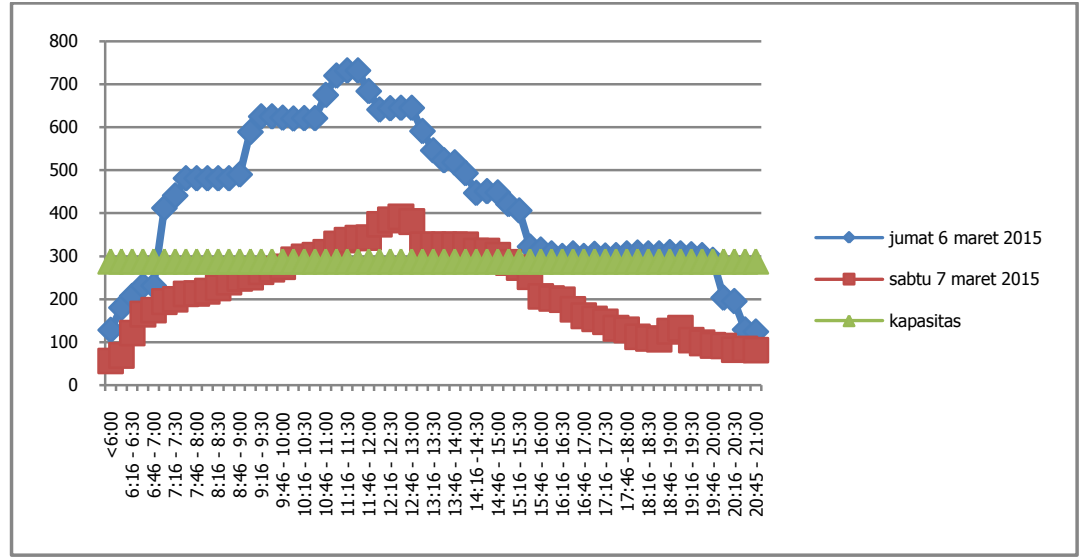

Sumber: Hasil Analisis, 2015

Gambar 7. Akumulasi Motor terhadap Kapasitas Parkir Sisi Utara

Sumber: Hasil Analisis, 2015

Gambar 8. Grafik Indeks Parkir Motor terhadap Standar Indeks Parkir Sisi Selatan

\section{Kinerja Parkir berdasarkanPersepsi Pengguna Parkir dengan Model Kano}

\section{Hasil Analisis Deskriptif Pengguna Parkir}

Pada Tabel 5 dapat diketahui bahwa mayoritas pengguna parkir adalah pria karena survei dilakukan kepada pengendara motor dan mobil, penghasilan pengguna parkir <2juta-4juta karena UMR kota bekasi adalah Rp. 2,95 juta, pekerja karena survei dilakukan pada hari kerja, parkir perminggu 5 kali karena hari kerja, penguna moda motor karena kemacetan kota bekasi dan penguna kendaraan dengan berpenumpang 1 atau lebih ke Stasiun Bekasi karena waktu kerja dan sekolah bersamaan. 


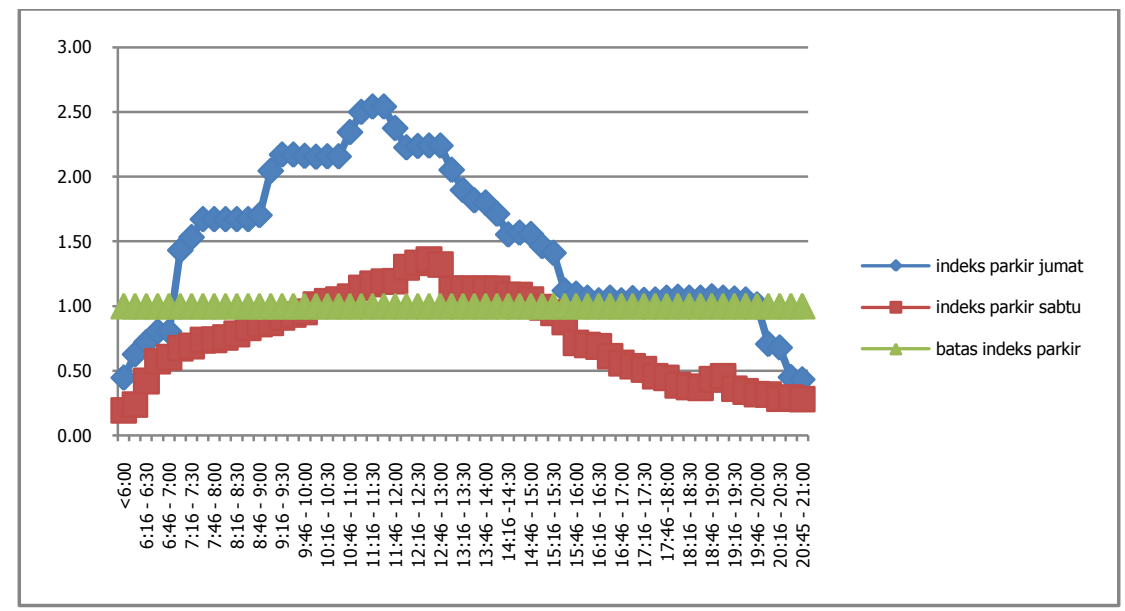

Sumber: Hasil Analisis, 2015

Gambar 9. Grafik Indeks Parkir Motor terhadap Standar Indeks Parkir Sisi Utara

Sumber: Hasil Analisis, 2015

\section{Gambar 10. Grafik Indeks Parkir Mobil terhadap Standar Indeks Parkir Sisi Utara}

Tabel 5.Hasil Analisis Deskriptif Pengguna Parkir di Stasiun Bekasi

\begin{tabular}{lll}
\hline No & Keterangan & \multicolumn{1}{c}{ Persentase } \\
\hline 1 & Jenis kelamin pengguna parkir & $68 \%$ pria, 32\% wanita \\
2 & Penghasilan pengguna parkir & $52 \%>2$ juta-4juta, 23\% >4juta-5juta, 22\% \\
& & $>5 j u t a, 3 \% 1$ juta-2juta \\
3 & Maksud perjalanan pengguna parkir & $78 \%$ bekerja, 9\% kuliah/sekolah, 6\% lain-lain, \\
& & $5 \%$ belanja, 2\% rekreasi \\
4 & Moda yang sering digunakan ke Stasiun Bekasi & $79 \%$ motor, 21\% mobil \\
5 & Parkir per minggu pengguna parkir & $50 \% 5$ kali, 17\% 6 kali, 15\% tidak tentu, 12\% 2 \\
& & kali, 6\% 7 kali \\
6 & Dengan siapa pengguna parkir menuju Stasiun & $74 \%$ lain-lain, 26\% sendiri \\
& Bekasi & \\
\hline
\end{tabular}

Sumber: Hasil Analisis, 2015 


\section{Hasil Model Kano}

Tabel 6 dapat menunjukan bahwa terdapat 15 atribut kinerja parkir berdasarkan persepsi pengguna parkir yang meliputi variabel keamanan, kenyamanan, kemudahan parkir, kinerja petugas parkir, tarif parkir, dan fasilitas tambahan.

\section{Tabel 6. Atribut Fasilitas Parkir Stasiun Bekasi}

\begin{tabular}{ll}
\hline Atribut & \\
\hline A1 & Pos keamanan yang dijaga petugas keamanan \\
A2 & Tempat penitipan helm \\
A3 & Fasilitas CCTV \\
B1 & Fasilitas kanopi \\
B2 & Papan petunjuk ketersediaan parkir di pintu masuk lahan parkir \\
C1 & Pemisahan lahan parkir mobil dan motor \\
C2 & Pemisahan pintu masuk dan keluar mobil dan motor \\
C3 & Garis parkir yang jelas dan sesuai standar \\
D1 & Petugas parkir yang sigap dalam memberikan informasi lahan parkir yang masih \\
& ada \\
D2 & Petugas parkir yang sigap mengatur parkir \\
E1 & E-parking reska yang telah menentukan tarif parkir yang berlaku sekarang \\
E2 & Tarif berlangganan untuk pengguna parkir \\
F1 & Fasilitas atm di lahan parkir \\
F2 & Fasilitas kiss and ride di lahan parkir \\
F3 & Fasilitas kafetaria di lahan parkir \\
\end{tabular}

Berdasarkan gambar 11 diketahui bahwa dalam kategori kano urutan pertama adalah must be dimana atribut yang masuk adalah garis parkir yang jelas dan sesuai standar (C3), petugas parkir yang sigap mengatur parkir (D2) dan petugas parkir yang sigap memberikan informasi lahan parkir yang masih ada (D1).

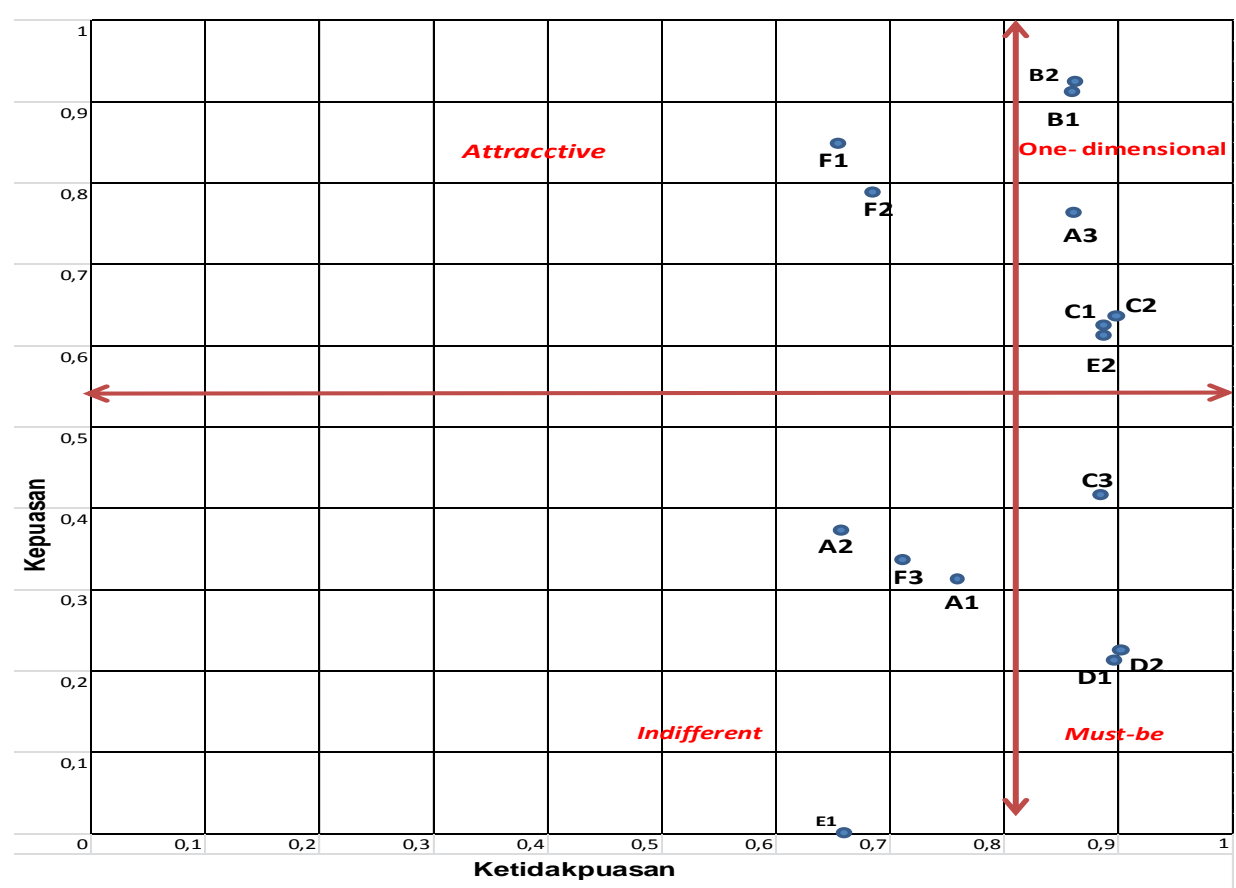

Sumber: Hasil Analisis, 2015

Gambar 11. Diagram Model kano Kepuasan dan Ketidakpuasan Pengguna Parkir di Stasiun Bekasi 


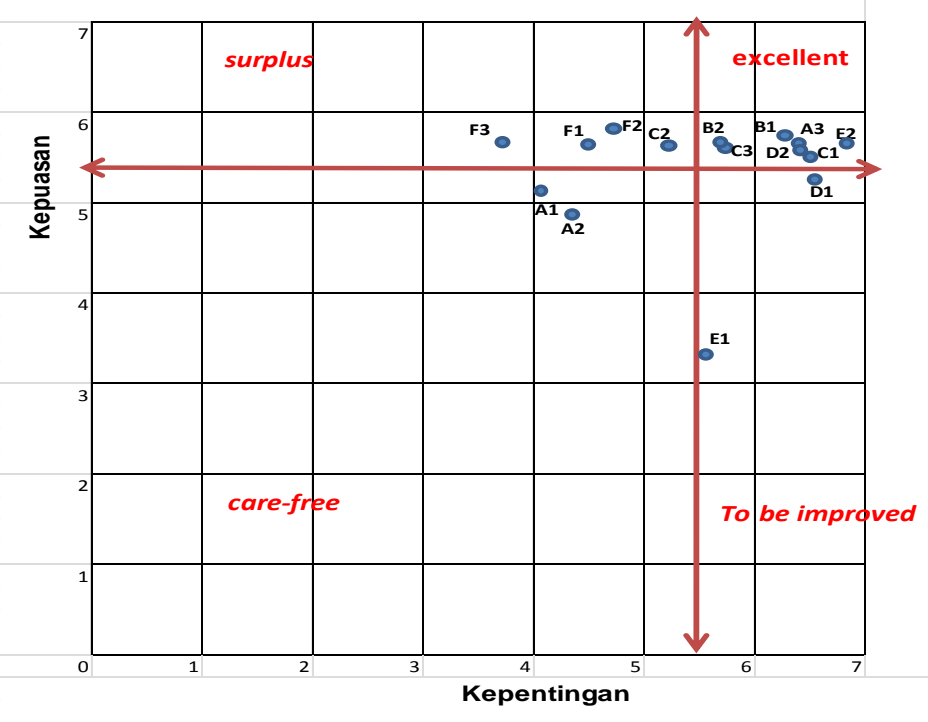

Sumber: Hasil Analisis, 2015

\section{Gambar 12. Diagram I-S Model Kano Pengguna Parkir di Stasiun Bekasi}

Atribut yang masuk dalam kategori excellent adalah garis parkir yang jelas dan sesuai standar (C3), petugas parkir yang sigap mengatur parkir (D2), tarif berlangganan untuk pengguna parkir (E2), pemisahan lahan parkir mobil dan motor (C1), fasilitas CCTV (A3), fasilitas kanopi (B1) dan papan petunjuk ketersediaan parkir (B2)yang dapat dilihat pada gambar 12.Prioritas perbaikan kinerja parkir di Stasiun Bekasi ada 12 atribut dimana prioritas utama adalah garis parkir yang jelas dan sesuai standar (C3) dapat dilihat padatabel 6.

Tabel 6.Prioritas Pengembangan Kinerja Parkir Di Stasiun Bekasi Berdasarkan Model Kano

\begin{tabular}{|c|c|c|c|}
\hline Prioritas & Atribut & Atribut & Keterangan \\
\hline 1 & 3 & Garis parkir yang jelas dan sesuai standar & Diterapkan \\
\hline 2 & D2 & Petugas parkir yang sigap mengatur parkir & Diperbaiki \\
\hline 3 & $\mathrm{D} 1$ & $\begin{array}{l}\text { Petugas parkir yang sigap dalam memberikan } \\
\text { informasi lahan parkir yang masih ada }\end{array}$ & Diperbaiki \\
\hline 4 & E2 & $\begin{array}{l}\text { Tarif berlangganan untuk pengguna kereta di } \\
\text { Stasiun Bekasi }\end{array}$ & Diterapkan \\
\hline 5 & $\mathrm{C} 1$ & Pemisahan lahan parkir mobil dan motor & Diterapkan \\
\hline 6 & A3 & Fasilitas CCTV & Diterapkan \\
\hline 7 & B1 & Fasilitas kanopi & Diterapkan \\
\hline 8 & B2 & $\begin{array}{l}\text { Papan petunjuk ketersediaan parkir di pintu masuk } \\
\text { lahan parkir }\end{array}$ & Diterapkan \\
\hline 9 & $\mathrm{C} 2$ & Pemisahan pintu masuk dan keluar mobil dan motor & Diperbaiki \\
\hline 10 & $\mathrm{~F} 1$ & Fasilitas ATM di lahan parkir & Diterapkan \\
\hline 11 & $\mathrm{~F} 2$ & Fasilitas kiss and ride & Diterapkan \\
\hline 12 & E1 & $\begin{array}{l}\text { E-parking reska yang telah menentukan tarif parkir } \\
\text { yang berlaku sekarang }\end{array}$ & Diterapkan \\
\hline 13 & F3 & Fasilitas kafetaria di lahan parkir & $\begin{array}{l}\text { Tidak mempengaruhi } \\
\text { kepuasan pengguna parkir }\end{array}$ \\
\hline 14 & A2 & Tempat penitipan helm & $\begin{array}{l}\text { Tidak mempengaruhi } \\
\text { kepuasan pengguna parkir }\end{array}$ \\
\hline 15 & A1 & Pos keamanan yang dijaga petugas keamanan & $\begin{array}{l}\text { Tidak mempengaruhi } \\
\text { kepuasan pengguna parkir }\end{array}$ \\
\hline
\end{tabular}




\section{Hasil Analytic Hierarchy Process (AHP)}

Tabel 7 menunjukan bahwa prioritas utama dalam penerapan park and ride di Stasiun Bekasi berdasarkan persepsi stakeholder adalah penyediaan lahan parkir sebesar $28,48 \%$.

Tabel 7. Tabel Penerapan Park and ride di Stasiun Bekasi (AHP)

\begin{tabular}{|c|c|c|c|}
\hline Kriteria & Bobot (\%) & Keterangan & Bobot (\%) \\
\hline Penyediaan & $28,48 \%$ & Parkir sepeda motor & $31,70 \%$ \\
\hline \multirow[t]{3}{*}{ lahan parkir } & & Parkir mobil & $36,06 \%$ \\
\hline & & Parkir kendaraan khusus difabel & $19,90 \%$ \\
\hline & & Parkir sepeda & $12,34 \%$ \\
\hline \multirow{3}{*}{$\begin{array}{l}\text { Keamanan } \\
\text { (security) }\end{array}$} & $24,38 \%$ & Menara pengawas & $13,06 \%$ \\
\hline & & Petugas keamanan & $39,63 \%$ \\
\hline & & CCTV & $47,31 \%$ \\
\hline \multirow[t]{4}{*}{ Kenyamanan } & $23,72 \%$ & Kiss and ride angkutan umum & $35,62 \%$ \\
\hline & & Kiss and ride kendaraan pribadi & $31,38 \%$ \\
\hline & & Ruang tunggu penumpang & $22,21 \%$ \\
\hline & & Parkir jangka pendek & $10,80 \%$ \\
\hline \multirow{2}{*}{ Aksesibilitas } & $12,49 \%$ & Jalur pejalan kaki tanpa fasilitas pelengkap & $16,94 \%$ \\
\hline & & $\begin{array}{l}\text { Jalur pejalan kaki dengan faslitas pelengkap } \\
\text { dan difabel }\end{array}$ & $83,06 \%$ \\
\hline \multirow[t]{4}{*}{ Kemudahan } & $10,93 \%$ & Mesin e-parking & $24,60 \%$ \\
\hline & & Petugas e-parking & $15,12 \%$ \\
\hline & & Kartu e-parking & $25,66 \%$ \\
\hline & & Petunjuk ketersediaan parkir & $34,62 \%$ \\
\hline
\end{tabular}

Sumber: Hasil Analisis, 2015

Berdasarkan gambar 13 dapat diketahui prioritas utama dalam penerapan park and ride di Stasiun Bekasi adalah penyediaan lahan parkir yang terdiri dari parkir mobil, parkir sepeda motor, parkir kendaraan khusus difabel dan parkir sepeda.

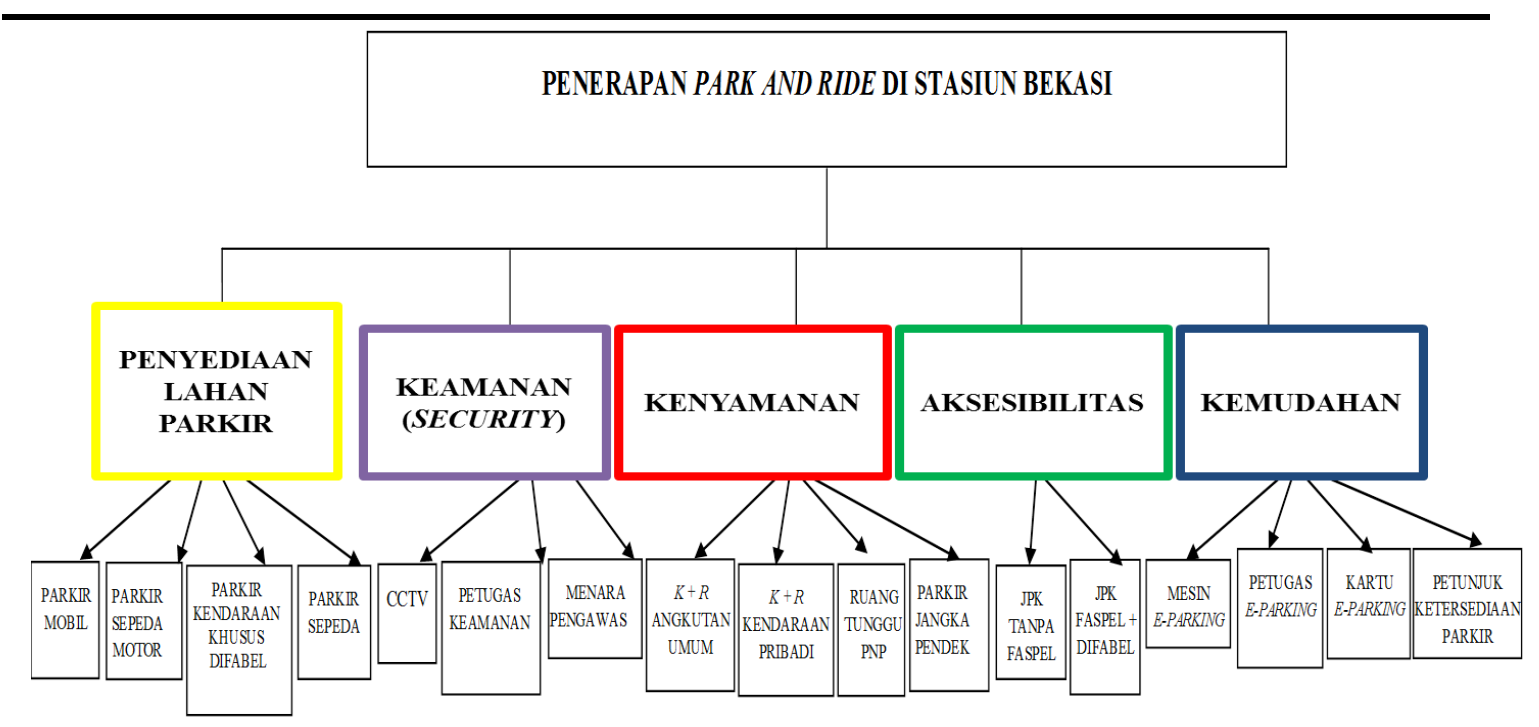

Sumber: Hasil Analisis, 2015

Gambar 13. Prioritas Penerapan Park and Ridedi Stasiun Bekasi 


\section{Kesimpulan}

Dari hasil kinerja parkir:

a.Berdasarkan standar pedoman teknis penyelenggaraan fasilitas parkir terdapat 7 permasalahan standar parkir di Stasiun Bekasi.

b.Berdasarkan persepsi pengguna parkir dengan Model Kano ada 12 atribut yang harus diperbaiki di Stasiun Bekasi dimana prioritas utama adalah garis parkir yang jelas dan sesuai standar di lahan parkir(C3).

Berdasarkan persepsi stakeholder, prioritas utama penerapan park and ride di Stasiun Bekasi yaitu penyediaan lahan parkir sebesar 28,48\%.

\section{Saran}

Untuk penelitian selanjutnya, diperlukan penilaian kinerja parkir dengan metode lain seperti SEM (Structural Equation Modeling),desain penerapan park and ride yang sesuai kondisi Stasiun Bekasi dengan melihat potensi pertumbuhan penumpang KRL (Kereta Rel Listrik) dan potensi pengguna parkir yang dikelola masyarakat.

Secara umum disarankan pemerintah memperhatikan kebutuhan pengguna parkir di Stasiun Bekasi dengan rekomendasi:

a. Rekomendasi jangka pendek adalah penyediaan lahan parkir dengan pembangunan gedung parkirsisi selatan dan sisi utara Stasiun Bekasi yang memenuhi persepsi pengguna parkir.

Bekasi.

b. Rekomendasi jangka panjang adalah penerapan park and ride di Stasiun

Secara khusus disarankan disarankan untuk masyarakat pengguna kendaraan pribadi dari Bekasi - Jakarta beralih menggunakan angkutan umum KRL dengan memarkirkan kendaraan pribadinya di Stasiun Bekasi.

\section{Daftar Pustaka}

BSTP. 2008, Pedoman teknis park and ride busway jabodetabek. Derektorat Bina Sistem Transportasi Perkotaan, Departemen Perhubungan.

Chronika, Lidia. Mangunsong, Lamria. dan Narsih, 2008. Analisis Kepuasan Konsumen terhadap Kualitas Pelayanan Parkir di Mega Mall A. Yani Pontianak. Jurnal. Politeknik Negeri Pontianak.

Departemen perhubungan, 1996.Keputusan Direktur Jenderal Perhubungan Darat Nomor: 272/HK.105/DJRD/96 tentang Pedoman teknis penyelenggaraan fasilitas parkir Direktorat Jenderal Perhubungan darat.

Dishub Kota Bekasi. 2012. Kajian analisis park and ride di Kota Bekasi, Bekasi: Dishub Kota Bekasi.

Farhan, B. 2003. Evaluation, modelling and policy assessment for park and ride service as a component of public transport. Unpublised.Disertation. Ohio State University.

Florida Department, 2012, State park and ride guide. Florida: Florida Department of Transport.

Ginn, Simon. 2009. The application of the park and ride and TOD concepts to develop a new frame work that can maximize public transport patronage, Tesis. Queensland University of Technology.

Halim, Melissa dan Megalara, Rona Nur. 2011. Evaluasi kapasitas dan kebutuhan parkir rumah sakit saiful anwar Malang dengan metode IPA dan SWOT.Skripsi tidak dipublikasikan. Malang: Universitas Brawijaya Malang

Hobbs, F.D., 1979. Traffic Planning and Engineering. Second edition. edisi Indonesia, 1995. terjemahan Suprapto T.M. dan Waldijono, Perencanaandan Teknik Lalu Lintas.Edisi kedua, Gadjah Mada University Press. Yogyakarta.

Nurfajriat. 2007. Kapasitas ruang parkir di lingkungan kampus dibandingkan dengan standar kebutuhan pengguna. Skripsi. Bandung: UNIKOM. 
Saaty, TL. 1990. How to make a decision: The analytic hierarchy process. European journal of operation research. 48(1): 9-26.

Virginia, J. 2013.Redesain Stasiun Bekasi dengan pendekatan desain arsitektur. Skripsi.Semarang: Universitas Diponogoro.

Yang, Ching Chow. 2005. The Refined Kano's Model and It's Application, Journal Total Quality Management Vol 16. No.10: 1127-1137. 